University of Nebraska - Lincoln

DigitalCommons@University of Nebraska - Lincoln

US Department of Energy Publications

U.S. Department of Energy

2004

\title{
Copper Sorption Mechanisms On Smectites
}

\author{
Daniel G. Strawn \\ University of Idaho \\ Noel E. Palmer \\ University of Idaho \\ Luca J. Furnare \\ University of Idaho \\ Carmen Goodell \\ University of Idaho \\ James E. Amonette \\ Pacific Northwest National Laboratory \\ See next page for additional authors
}

Follow this and additional works at: https://digitalcommons.unl.edu/usdoepub

Part of the Bioresource and Agricultural Engineering Commons

Strawn, Daniel G.; Palmer, Noel E.; Furnare, Luca J.; Goodell, Carmen; Amonette, James E.; and Kukkadapu, Ravi K., "Copper Sorption Mechanisms On Smectites" (2004). US Department of Energy Publications. 141. https://digitalcommons.unl.edu/usdoepub/141

This Article is brought to you for free and open access by the U.S. Department of Energy at DigitalCommons@University of Nebraska - Lincoln. It has been accepted for inclusion in US Department of Energy Publications by an authorized administrator of DigitalCommons@University of Nebraska - Lincoln. 


\section{Authors}

Daniel G. Strawn, Noel E. Palmer, Luca J. Furnare, Carmen Goodell, James E. Amonette, and Ravi K. Kukkadapu 


\title{
COPPER SORPTION MECHANISMS ON SMECTITES
}

\author{
Daniel G. Strawn ${ }^{1}{ }^{*}$, Noel E. Palmer ${ }^{1}$, Luca J. Furnare ${ }^{1}$, Carmen Goodell ${ }^{1}$, \\ James E. Amonette ${ }^{2}$ and Ravi K. Kuknadapu ${ }^{2}$ \\ ${ }^{1}$ Department of Plant, Soil and Entomological Sciences, University of Idaho, Moscow, ID 83844-2339, USA \\ ${ }^{2}$ Pacific Northwest National Laboratory, Richland, Washington, USA
}

\begin{abstract}
Due to the importance of clay minerals in metal sorption, many studies have attempted to derive mechanistic models that describe adsorption processes. These models often include several different types of adsorption sites, including permanent charge sites and silanol and aluminol functional groups on the edges of clay minerals. To provide a basis for development of adsorption models it is critical that molecular-level studies be done to characterize sorption processes. In this study we conducted X-ray absorption fine structure (XAFS) and electron paramagnetic resonance (EPR) spectroscopic experiments on copper (II) sorbed on smectite clays using suspension $\mathrm{pH}$ and ionic strength as variables. At low ionic strength, results suggest that $\mathrm{Cu}$ is sorbing in the interlayers and maintains its hydration sphere. At high ionic strength, $\mathrm{Cu}$ atoms are excluded from the interlayer and sorb primarily on the silanol and aluminol functional groups of the montmorillonite or beidellite structures. Interpretation of the XAFS and EPR spectroscopy results provides evidence that multinuclear complexes are forming. Fitting of extended X-ray absorption fine structure spectra revealed that the $\mathrm{Cu}-\mathrm{Cu}$ atoms in the multinuclear complexes are $2.65 \AA$ apart, and have coordination numbers near one. This structural information suggests that small $\mathrm{Cu}$ dimers are sorbing on the surface. These complexes are consistent with observed sorption on mica and amorphous silicon dioxide, yet are inconsistent with previous spectroscopic results for $\mathrm{Cu}$ sorption on montmorillonite. The results reported in this paper provide mechanistic data that will be valuable for modeling surface interactions of $\mathrm{Cu}$ with clay minerals, and predicting the geochemical cycling of $\mathrm{Cu}$ in the environment.
\end{abstract}

Key Words-Copper, EPR, EXAFS, Montmorillonite, Smectite, Sorption.

\section{INTRODUCTION}

An important characteristic of clay minerals is their large cation adsorption capacity. The classic model of cation adsorption on clay minerals implies that adsorption occurs in the interlayers via electrostatic interactions (outer-sphere adsorption complexes) (Marshal, 1935; Sposito, 1989). Recent research suggests that inner-sphere adsorption on ligand functional groups located at mineral discontinuities (edges, steps and kinks) of clay minerals is also important (Bradbury and Baeyens, 1999; Dahn et al., 2003; Morton et al., 2001; Papelis and Hayes, 1996; Schlegel et al., 1999; Zachara et al., 1993). Evidence for the existence of inner-sphere complexation has been provided by theoretical modeling of metal sorption behavior (Helmy et al., 1994; Schindler et al., 1987; Stadler and Schindler, 1993; Undabeytia et al., 2002; Zachara and McKinley, 1993). However, this approach often suffers from lack of molecular-level evidence of the sorption processes. Schlegel et al. (1999) and Dahn et al. (2003) used polarized EXAFS spectroscopy to provide direct evidence for the formation of inner-sphere linkages of Co and $\mathrm{Ni}$, respectively, on clay minerals without the formation of multinuclear complexes.

* E-mail address of corresponding author: dgstrawn@uidaho.edu

DOI: $10.1346 /$ CCMN.2004.0520307
Many researchers investigating edge-site sorption on clay minerals have instead observed multinuclear complexes (Hyun et al., 2000; Morton et al., 2001; O'Day et al., 1994; Strawn and Sparks, 1999). The existence of multinuclear metal complexes on clay minerals has been shown for several metals, including $\mathrm{Pb}, \mathrm{Co}, \mathrm{Cu}, \mathrm{Cd}, \mathrm{Ni}$ and Zn (Di Leo and O'Brien, 1999; Morton et al., 2001; O'Day et al., 1994; Papelis and Hayes, 1996; Schlegel et al., 2001). Of particular interest is that these complexes are forming in systems in which they are not predicted to be present in aqueous solution based on known thermodynamic equilibrium constants. The occurrence of multinuclear complexes in clay suspensions undersaturated with respect to the metal hydrolysis complexes suggests that clay minerals are enhancing their formation. Three common hypotheses are often presented to explain enhanced surface precipitation: (1) due to the surface charge, the properties of the water molecules next to the surface are altered (dielectric saturation); this has direct impacts on metal hydrolysis equilibrium; (2) stearic or nucleation enhancement occurs due to multi-layer sorption on specific sorption sites; and (3) mixed-cation multinuclear complexes form using cations in solution and cations dissolved from the mineral (solid-solution) (O’Day et al., 1994; Strawn and Sparks, 1999; Towle et al., 1997). While multinuclear complex formation on clay minerals has been suggested for many years (McBride, 1982b), recent advances in molecular spectroscopy have made it 
possible to make direct observations into the molecular structure and location of these complexes.

The present research is focused on the transition metal copper. Several papers have reported the occurrence of multinuclear $\mathrm{Cu}$ complexes on minerals (Cheah et al., 2000; Farquhar et al., 1996; McBride, 1982a; McBride and Bouldin, 1984; Morton et al., 2001; Weesner and Bleam, 1997). McBride (1982b) assigned the loss of EPR signal intensity in hectorite suspensions undersaturated with respect to $\mathrm{Cu}(\mathrm{OH})_{2}$ (s) to the formation of aqueous multinuclear complexes such as $\mathrm{Cu}_{2}(\mathrm{OH})_{2}^{2+}$ in the clay interlayer. Ford and Sparks (1998) reported that $\mathrm{Cu}$ sorbed onto pyrophyllite lacked a second neighbor atom, while $\mathrm{Zn}$ sorbed under similar equilibration conditions formed a vast multinuclear mixed-cation precipitate.

Morton et al. (2001) used extended X-ray absorption fine structure (EXAFS) spectroscopy to determine how equilibrium conditions (ionic strength $(I)$ and $\mathrm{pH}$ ) impact $\mathrm{Cu}$ complexation mechanisms on montmorillonite. At low ionic strength and $\mathrm{pH}$, sorbed $\mathrm{Cu}$ was observed to maintain its hydration sphere, while at higher ionic strengths and $\mathrm{pH}$, sorbed $\mathrm{Cu}$ had second-shell $\mathrm{Cu}$ atoms located $2.98 \AA$ apart, indicating that the sorbed $\mathrm{Cu}$ existed in a multinuclear complex with structural similarities to $\mathrm{Cu}(\mathrm{OH})_{2}$ (s) (Morton et al., 2001). Farquhar et al. (1996) investigated $\mathrm{Cu}$ complexation on the (001) mica surface using EXAFS spectroscopy and X-ray photoelectron spectroscopy (XPS) and observed the formation of multinuclear complexes having $\mathrm{Cu}-\mathrm{Cu}$ distances of $2.65 \AA$. $\mathrm{Cu}-\mathrm{Cu}$ bond distances of $2.65 \AA$ have been reported for $\mathrm{Cu}$ in the $\mathrm{Cu}$-silicate mineral plancheite and for $\mathrm{Cu}$ sorbed on amorphous silica (Cheah et al., 1998; Farquhar et al., 1996). Cheah et al. (1998) noted that at low loading levels $\mathrm{Cu}$ formed small $\mathrm{Cu}$ dimers on the surface of $\mathrm{SiO}_{2}$, and as the surface loading increased, multinuclear complexes consistent with $\mathrm{Cu}(\mathrm{OH})_{2}$ (s) formed (Cheah et al., 2000).

In this study we are investigating $\mathrm{Cu}$ sorption on montmorillonite and beidellite as a function of varying ionic strength and $\mathrm{pH}$. In contrast to the study of Morton et al. (2001), we have selected initial equilibrium conditions that are undersaturated with respect to $\mathrm{CuO}$ (s), thus resulting in lower loading levels, and used $\mathrm{Ca}^{2+}$ as the competing ion to isolate more effectively the permanent charge sites in the interlayers. Results from this study will support the development of a mechanistic understanding for the enhanced formation of multinuclear metal complexation by clay minerals.

\section{METHODS}

\section{Clay minerals}

SWy-2 montmorillonite and SBId-1 beidellite were purchased from the Source Clays Repository (Purdue University, Indiana). Beidellite is a dioctahedral clay mineral with isomorphic substitution occurring predo- minantly in the tetrahedral sheet, as opposed to montmorillonite that has isomorphic substitution in the octahedral sheet. Preparation of the clay minerals entailed grinding in a ball mill to reduce particle size, successive treatment with $\mathrm{Na}$ hypochlorite at $50^{\circ} \mathrm{C}$ to remove trace amounts of organic matter, washing at $50^{\circ} \mathrm{C}$ with acetate buffer solution to dissolve carbonates, saturation with $\mathrm{Na}$ ions, complete dialysis to remove non-sorbed ions and chemicals, particle-size separation via centrifugation to isolate the $0.2-2 \mu \mathrm{m}$ size fraction, and freeze drying to dry the clays into powders. X-ray diffraction and diffuse reflectance-Fourier transform infrared (DRIFT) measurements were made on the treated clay to ensure purity. To test for the influence of free Fe oxyhydroxides, selected samples were treated with citrate-bicarbonate-dithionite solution (CBD) to remove any Fe minerals. The XAFS spectroscopy results (data not shown) for the CBD-treated clays were identical to non-CBD-treated samples.

\section{pH edges}

All experiments were conducted using deionized water that was boiled and cooled by degassing with $\mathrm{N}_{2}(\mathrm{~g})$. Copper solutions were made from nitrate salts. Sorption-pH edges were conducted at two ionic strengths, $0.001 \mathrm{M}$ and $0.1 \mathrm{M}$ calcium nitrate. Experiments comparing $\mathrm{Ca}, \mathrm{Mg}, \mathrm{K}$ and $\mathrm{Na}$ showed that $\mathrm{Ca}$ is much more effective at excluding $\mathrm{Cu}$ from the interlayers than the other cations.

At the onset of the experiments, the clay minerals were preequilibrated in the background electrolytes at $\mathrm{pH}=4$ for $24 \mathrm{~h}$. The solid-solution ratio was $10 \mathrm{~g} \mathrm{~L}^{-1}$. Following preequilibration, the clays were spiked with a $\mathrm{Cu}$ stock solution to achieve a final $\mathrm{Cu}$ concentration of $3.6 \times 10^{-5} \mathrm{M}$. After the clay suspensions were spiked, the samples were allowed to mix for $10 \mathrm{~min}$. Next, a $10 \mathrm{~mL}$ aliquot was removed and placed in a centrifuge tube. The $\mathrm{pH}$ of the bulk suspension was increased by $0.5 \mathrm{pH}$ unit increments, and $10 \mathrm{~mL}$ subsamples were removed at each increment and placed in centrifuge tubes for equilibration. The samples were incubated for $24 \mathrm{~h}$ on an end-over-end shaker at $23-26^{\circ} \mathrm{C}$. Following equilibration, the samples were centrifuged and filtered through a membrane filter $(0.2 \mu \mathrm{m})$. Solutions were acidified by adding 1 drop $(\sim 0.1 \mathrm{~mL})$ of concentrated nitric acid. Aqueous metal concentrations were determined by inductively coupled plasma atomic emission spectroscopy (ICP-AES) using NIST traceable standards. The amount of metal sorbed was calculated from the difference between the initial and final aqueous metal concentrations. Initial concentration was taken from a blank (no clay) run through the experiment at $\mathrm{pH} \approx 3$.

\section{XAFS sample preparation}

To prepare samples for XAFS analysis, $30 \mathrm{~mL}$ of clay suspensions (1:50 solid:solution gravimetric) were placed in dialysis bags (Spectrapor 3500 dalton) and 
suspended in $970 \mathrm{~mL}$ of $4.0 \times 10^{-5} \mathrm{M} \mathrm{Cu}$ solution with $I$ and $\mathrm{pH}$ preadjusted. After $8-12 \mathrm{~h}$ of incubation, the $\mathrm{Cu}$ solution was replaced with fresh $\mathrm{Cu}$ solution, $\mathrm{pH}$ preadjusted. The $\mathrm{pH}$ was monitored and adjusted throughout the equilibration. The high solid to solution ratio (effectively 1/1000), and replenishment of $\mathrm{Cu}$ solution allowed us to load the clays with high concentrations of $\mathrm{Cu}$ without having high aqueous $\mathrm{Cu}$ concentrations, thereby avoiding oversaturation with respect to $\mathrm{Cu}$ (hydr)oxides. The $\mathrm{Cu}$ concentration was selected so that the initial $[\mathrm{Cu}]$ in all samples was below the concentration at which $\mathrm{Cu}$ precipitation or hydrolysis is expected. Copper hydrolysis and precipitation speciation were evaluated using constants in the Mineql database (Schecher, 1998) and from Baes and Mesmer (1986). At the equilibration conditions used in our experiments, $\mathrm{CuO}$ (s) is the least soluble $\mathrm{Cu}$ mineral. A $\mathrm{CuO}(\mathrm{s})$ solubility diagram is shown in Figure 1, along with sample equilibration conditions used in these experiments.

\section{XAFS experiments}

The XAFS data acquisition of the $\mathrm{Cu}$ K-edge $(8979 \mathrm{eV})$ was conducted on beamline 4 at stations 4.1, 4.2 and 4.3 at the Stanford Synchrotron Radiation Laboratory (SSRL). The electron beam energy was $3 \mathrm{GeV}$, and the beam current ranged from 100 to $60 \mathrm{~mA}$. The monochromator consisted of two parallel

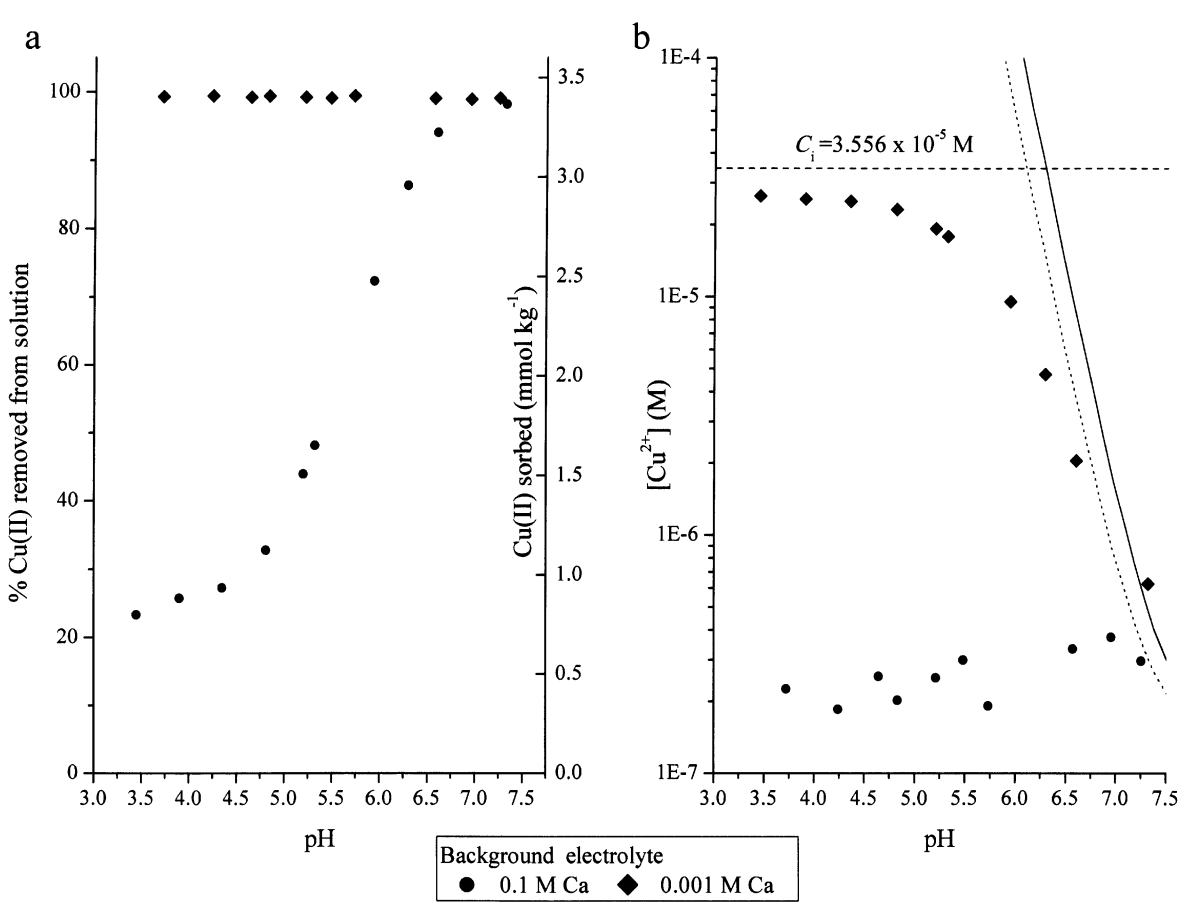

Figure 1. Sorption behavior of $\mathrm{Cu}$ on montmorillonite as a function of $\mathrm{pH}$ and ionic strength $(I)$. Montmorillonite concentration was $10 \mathrm{~g} \mathrm{~L}^{-1}$, initial $\mathrm{Cu}$ concentration $\left(C_{\mathrm{i}}\right)$ was $3.6 \times 10^{-5} \mathrm{M}$. Figure 1a show the percentage of $\mathrm{Cu}$ left in solution and the sorbed $\mathrm{Cu}$ concentration (right axis). Figure $1 \mathrm{~b}$ shows the equilibrium $[\mathrm{Cu}]$ in the $\mathrm{Ca}$ background electrolyte experiment as a function of $\mathrm{pH}$, as well as the solubility line for tenorite $(\mathrm{CuO})$ at two ionic strengths. The solid line in $1 \mathrm{~b}$ is $\mathrm{CuO}$ solubility at $I=0.001$ and dotted line is $\mathrm{CuO}$ solubility at $I=0.1$.

$\operatorname{Si}(111)$ crystals with an entrance slit of $2 \mathrm{~mm}$. Harmonic rejection was achieved by detuning the second crystal $40 \%$. For X-ray absorption near edge structure (XANES) data collection, the mono-entrance slit was decreased to $1 \mathrm{~mm}$ and detuning was reduced to $30 \%$ to increase resolution and signal counts, respectively. The XAFS data were collected in fluorescence mode using a 13-element $\mathrm{Ge}$ detector. The spectra of $\mathrm{Cu}$ standards were collected in fluorescence mode using an argon purged Stern-Heald type detector (Lytle et al., 1984), as well as transmission using $\mathrm{N}_{2}$-filled ionization chambers. Clay-mineral samples were loaded in a plastic sample cell, sealed with Kapton ${ }^{\circledR}$ tape, and stored in airtight plastic bags until analysis. Standards were diluted in boron nitride to achieve the desired absorbance. $\mathrm{A} \mathrm{Cu}$ foil was used in all experiments as an internal standard to calibrate the beam energy. The spectra were collected at room temperature ( 298 K).

The XAFS data analysis was accomplished using the program WinXAS (Ressler, 1998) and FEFF8.0 (Ankudinov et al., 1998). The spectra were processed using the following procedure: (1) multiple scans were merged and energy calibrated to the $\mathrm{Cu}$ K-edge $(8979 \mathrm{eV})$; (2) the spectra were normalized to unit-step height using a linear pre- and post-edge background subtraction; (3) the spectra were transformed to k-space using the inflection point of the sample-edge jump; (4) the $\chi$-function was extracted from the raw data by 
subtracting the atomic background using a cubic-spline consisting of 5 knots set at equal distances fit to $\mathrm{k}^{3}$-weighted data; and (5) the data were Fourier transformed (FT) to isolate individual frequencies in the $\chi\left(\mathrm{k}^{3}\right)$ spectra (k range for FT was $\sim 3.4-11.8 \AA^{-1}$ ). For background removal (step 4), the window width was optimized using qualitative assessment of the resulting $\chi$ and Fourier transform.

The XANES spectra were transformed by taking the first derivative of the normalized spectra and smoothed using a smoothing function (Savitzky and Golay, 1964). Since the signal to noise level for the samples equilibrated at high $I$ was low, the three samples were merged to improve the resolution of the data. This was deemed reasonable since the three spectra appeared identical in shape and magnitude of features.

Theoretical backscattering phase and amplitude functions for $\mathrm{Cu}-\mathrm{Cu}$ backscatterers and $\mathrm{Cu}-\mathrm{O}$ backscatterers were calculated using the FEFF8.0 code, with an input file based on a model of Tenorite $(\mathrm{CuO})$ (generated with the program WebATOMS 1.4 (Ravel, 2001)). Functions for $\mathrm{Cu}-\mathrm{Al}$ backscatterers were calculated by substituting an $\mathrm{Al}$ atom for a $\mathrm{Cu}$ atom in the second shell of the input file. During fitting, the value of the Debye Waller term $\left(\sigma^{2}\right)$ for the second shell $\mathrm{Cu}$ backscatterer was fixed at $0.008 \AA^{2}$. Fixing the $\sigma^{2}$ reduced the number of free parameters in the fitting routine, and $0.008 \AA^{2}$ is consistent with the value used by other researchers to fit second-shell $\mathrm{Cu}$ sorption data (Cheah et al., 1998, 2000; Farquhar et al., 1996; Morton et al., 2001). The edge shift $\left(E_{\mathrm{o}}\right)$ for all shells was constrained to be equal. An amplitude reduction factor (0.77) was determined by fitting the theoretical single scattering $\mathrm{O}$ and $\mathrm{Cu}$ shells to the same shells of the experimental spectra from well-characterized $\mathrm{Cu}(\mathrm{OH})_{2}$ mineral (Sigma Chemicals). In all cases the number of independent variables in the fitting routine was less than the degrees of freedom (Stern, 1988). Absolute errors of the fitting results are $1 \%$ for bond distances, $<20 \%$ for first-shell coordination numbers, and $25 \%$ for secondshell coordination numbers. Accuracies were verified by fitting well characterized reference materials $\left(\mathrm{Cu}(\mathrm{OH})_{2}\right.$ and $\mathrm{CuO}$ ) and comparing the fitted bond distances and coordination numbers with XRD-derived structural parameters. Standard deviations estimated from the diagonal elements of the covariance matrix from the least-squares refinement were $<1 \%$ for all varied parameters.

\section{EPR spectroscopy experiments}

Samples were prepared for electron paramagnetic resonance (EPR) spectroscopy experiments using the same procedures as described above for the XAFS spectroscopy experiments. The wet pastes were loaded into $1.1 \mathrm{~mm}$ O.D. $\times 0.9 \mathrm{~mm}$ I.D. clear fused-quartz cells and sealed with a polymer putty. Samples were analyzed at room temperature at a frequency of $9.387 \mathrm{GHz}$ and microwave power of $2.0 \mathrm{~mW}$ using a Bruker Instruments ESP 300E spectrometer. A sweep of $2000 \mathrm{G}$ centered at $2900 \mathrm{G}$ was used for the EPR scans. Samples were scanned up to seven times to increase the signal to noise ratio. The scans were merged and centered for comparison. For presentation purposes, the ordinate scale on the graphs was varied; however, assuming the size of the free radical resonance $\left(g_{e}\right)$ is consistent with the amount of sample in the microwave cavity, relative differences in peak height can be estimated from the graphs.

\section{RESULTS}

\section{pH-edge results}

Results from the $\mathrm{pH}$-edge experiments are presented in Figure 1. For the low- $I$ equilibrated samples there is little variation in sorption with $\mathrm{pH}$. The large negative charge on the interlayer sites that is balanced with $\mathrm{Na}^{+}$ can be displaced easily by divalent $\mathrm{Cu}^{2+}$ cations. This cation exchange is not $\mathrm{pH}$ dependent since the charge develops from isomorphic substitution and the ion attraction is electrostatic.

At high ionic strength, the increased concentration of background electrolyte cations $\left(\mathrm{Ca}^{2+}\right)$ out-compete $\mathrm{Cu}^{2+}$ for interlayer sites. As $\mathrm{pH}$ increased, sorption also increased until $100 \%$ of the $\mathrm{Cu}$ was removed from solution at $\mathrm{pH} 7$. Note that at this $\mathrm{pH}$ the initial $\mathrm{Cu}$ solution was saturated with respect to $\mathrm{CuO}(\mathrm{s})$ which is the least soluble $\mathrm{Cu}$ mineral under the conditions of this experiment. However, it is unlikely that $\mathrm{CuO}(\mathrm{s})$ formed since the clay mineral was titrated from low $\mathrm{pH}$ where sorption occurred below saturation, reducing the $\mathrm{Cu}$ concentration before saturation was reached at the higher $\mathrm{pH}$.

\section{XANES results}

Copper loading levels and final $\mathrm{pH}$ for the clay mineral samples are posted in Table 1. First derivatives of the Kedge XANES spectra from the samples and standards are presented in Figure 2. There are three unique features observed in the spectra that can be used to interpret local atomic structure of the $\mathrm{Cu}$-clay complexes: (1) pre-edge features; (2) edge features; and (3) near-edge features. The pre-edge feature occurring at $8976 \mathrm{eV}$ is due to a $1 \mathrm{~s}-3 \mathrm{~d}$ orbital transition that results from both octahedral and tetrahedral coordination. The existence of this peak is sensitive to a center of symmetry; the peak increases in intensity with distortions that remove the center of symmetry (Palladrino et al., 1993; Xia et al., 1997a). Similarity in the magnitude of the pre-edge peak in the XANES of the sorption samples to aqueous $\mathrm{Cu}$ indicates that the sorbed $\mathrm{Cu}$ has a distinct asymmetric first atomic shell similar to aqueous $\mathrm{Cu}$.

In the XANES spectra there exist two peaks in the first derivative spectra between 8983 and $8992 \mathrm{eV}$ that comprise the absorption edge. These peaks (labeled $\alpha$ and $\beta$ ) are a result of the main $1 \mathrm{~s}-4 \mathrm{p}$ orbital transitions (Palladrino et al., 1993; Xia et al., 1997a). The splitting 
Table 1. Fitting results for $\mathrm{Cu}(\mathrm{II})$ sorbed on clay minerals and reference standards.

\begin{tabular}{|c|c|c|c|c|c|c|c|c|c|c|}
\hline \multirow{2}{*}{ Sample } & \multirow[b]{2}{*}{$I$} & \multirow[b]{2}{*}{$\mathrm{pH}$} & \multirow{2}{*}{$\begin{array}{c}\text { Loading } \\
\left(\mathrm{mmol} \mathrm{kg}^{-1}\right)\end{array}$} & \multicolumn{3}{|c|}{$\mathrm{Cu}-\mathrm{O}$ shell } & \multicolumn{3}{|c|}{$\mathrm{Cu}-\mathrm{Cu}$ shell } & \multirow[b]{2}{*}{$E_{\mathrm{o}}(\mathrm{eV})$} \\
\hline & & & & $R(\AA)^{\mathrm{a}}$ & $N^{\mathrm{b}}$ & $\sigma^{2}\left(\AA^{2}\right)^{c}$ & $R(\AA)$ & $N$ & $\sigma^{2}\left(\AA^{2}\right)^{\mathrm{d}}$ & \\
\hline \multicolumn{11}{|c|}{ Montmorillonite } \\
\hline & 0.0001 & 4.01 & 59.1 & 1.96 & 4.51 & 0.005 & & & & 3.97 \\
\hline & 0.0001 & 5.49 & 108 & 1.96 & 4.27 & 0.004 & & & & 1.68 \\
\hline & 0.0001 & 5.90 & 96.1 & 1.95 & 4.19 & 0.004 & & & & 2.37 \\
\hline & 0.1 & 5.09 & 12.3 & 1.94 & 4.52 & 0.006 & 2.66 & 0.47 & 0.008 & 0.44 \\
\hline & 0.1 & 5.61 & 12.2 & 1.94 & 4.48 & 0.005 & 2.63 & 0.60 & 0.008 & 0.44 \\
\hline & 0.1 & 6.12 & 25.7 & 1.95 & 4.50 & 0.006 & 2.62 & 0.60 & 0.008 & 2.84 \\
\hline \multicolumn{11}{|l|}{ Beidellite } \\
\hline & 0.1 & 6.16 & 19.2 & 1.95 & 3.99 & 0.006 & 2.65 & 0.54 & 0.008 & 0.66 \\
\hline \multicolumn{11}{|l|}{ Standards } \\
\hline \multirow{3}{*}{$\begin{array}{r}\mathrm{CuOH}_{2} \\
\mathrm{XRD}^{\mathrm{e}}\end{array}$} & & & & 1.95 & 3.97 & 0.004 & 2.96 & 1.96 & 0.005 & 7.39 \\
\hline & equatorial & & & $1.95-1.97$ & 4.00 & & 2.95 & 2.00 & & \\
\hline & axial & & & $2.36-2.92$ & 2.00 & & & & & \\
\hline \multirow[t]{2}{*}{$\mathrm{CuO}$} & & & & 1.96 & 3.23 & 0.006 & 2.91 & 3.40 & 0.008 & 9.05 \\
\hline & & & & & & & 3.10 & 3.02 & 0.008 & \\
\hline \multirow[t]{3}{*}{$\mathrm{XRD}^{\mathrm{e}}$} & equatorial & & & $1.95-1.96$ & 4.00 & & 2.90 & 4.00 & & \\
\hline & & & & & & & 3.08 & 4.00 & & \\
\hline & axial & & & 2.78 & 2.00 & & & & & \\
\hline \multirow{3}{*}{$\begin{array}{c}\mathrm{Cu} \text { acetat } \\
\mathrm{XRD}^{\mathrm{e}}\end{array}$} & & & & 1.95 & 3.24 & 0.004 & 2.61 & 0.84 & 0.008 & 5.08 \\
\hline & equatorial & & & $1.95-1.99$ & 4.00 & & 2.62 & 1.00 & & \\
\hline & axial & & & 2.16 & 1.00 & & & & & \\
\hline \multirow{3}{*}{$\begin{array}{c}\mathrm{Cu}^{2+}(\mathrm{aq}) \\
\mathrm{XAFS}^{\mathrm{f}}\end{array}$} & & & & 1.96 & 4.02 & 0.004 & & & & 1.47 \\
\hline & equatorial & & & 1.97 & 4.00 & 0.004 & & & & \\
\hline & axial & & & 2.26 & 2.00 & 0.014 & & & & \\
\hline
\end{tabular}

a bond distances; ${ }^{\mathrm{b}}$ coordination number; ${ }^{\mathrm{c}}$ Debye Waller factor; ${ }^{\mathrm{d}}$ fixed; ${ }^{\mathrm{e}}$ from Cheah et al. $(2000) ;{ }^{\mathrm{f}}$ from Ozutsumi et al. (1991)

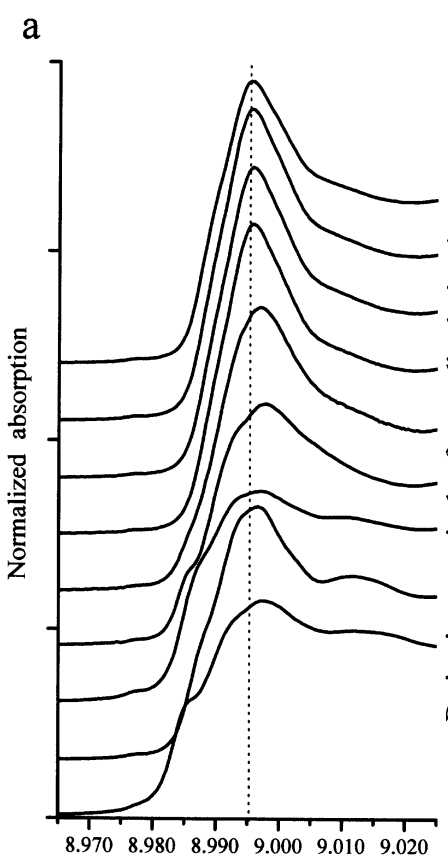

keV

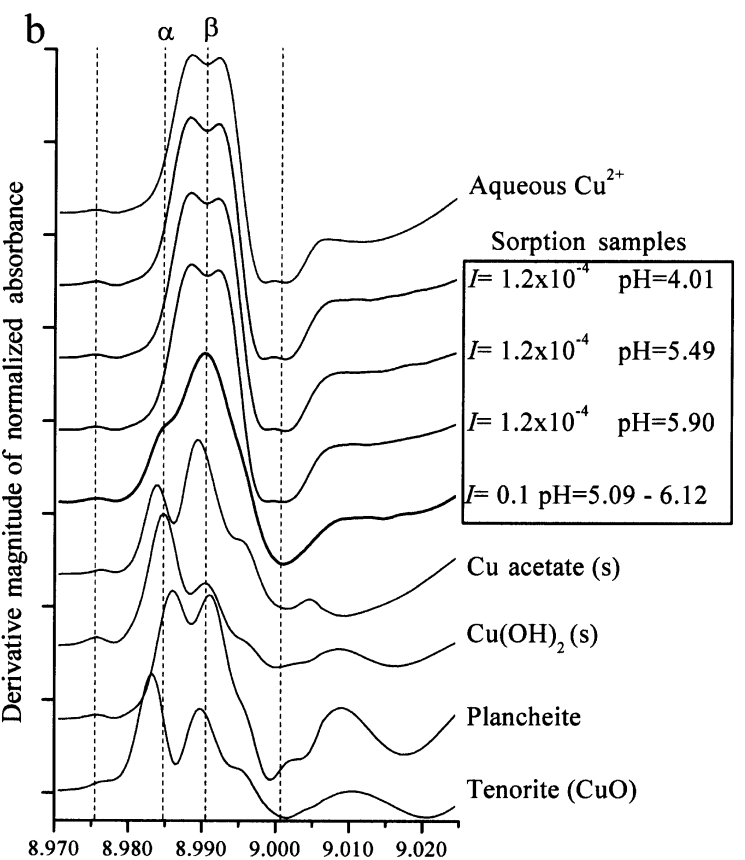

keV

Figure 2. (a) XANES and (b) first derivative of XANES of Cu sorbed onto montmorillonite and selected reference materials. Vertical dashed lines are aligned with peaks of interest. $I=0.1$ XANES is an average of three different samples $($ see text). 
of the main K-edge absorption peak is the subject of debate. Kau et al. (1987) reported that with increasing covalency there is an increased intensity of the $\alpha$ peak between 8983 and $8985 \mathrm{eV}$. The cause of this decreased excitation energy is reported to be a result of either the decrease in p-orbital energy that arises from the sharing of metal-d electrons with ligands (Kau et al., 1987), or a change in the axial-bond distances upon covalent bonding and the resulting multiple scattering off of the axial ligands (Palladrino, 1993). The decreased energy of the $\alpha$ peak is consistent with $\mathrm{Cu}$ complexes that have covalent character. Specifically, the features at $8985 \mathrm{eV}$ and $8990 \mathrm{eV}$ in the high- $I$ samples are directly in line with the features in the $\mathrm{Cu}(\mathrm{OH})_{2}$ mineral. However, the peak intensities in the high- $I$ samples are different than in $\mathrm{Cu}(\mathrm{OH})_{2}$ (s), indicating that the local atomic structure or size of the sorption complexes is different. In the samples equilibrated at low $I$ both $\alpha$ and $\beta$ peaks are in the same positions as $\mathrm{Cu}$ (aq), suggesting that the sorbed $\mathrm{Cu}(\mathrm{II})$ retains its hydration sphere.

In the first oscillations directly following the edge (near edge), the shape and features in the spectra are influenced by the local atomic structure surrounding the central absorber atom. The near-edge features in the low- $I$ equilibrated samples are nearly identical to aqueous $\mathrm{Cu}^{2+}$. The near-edge features in the high- $I$ equilibrated samples are distinctly different from the low- $I$ equilibrated samples, and are similar in energy position to $\mathrm{Cu}(\mathrm{OH})_{2}$ (s). However, as with the edge features, there are distinct differences in the near-edge features between the high- $I$ samples and the $\mathrm{Cu}(\mathrm{OH})_{2}$ mineral, again suggesting that the local atomic structure of sorbed $\mathrm{Cu}$ is different from the local atomic structure of $\mathrm{Cu}$ in $\mathrm{Cu}(\mathrm{OH})_{2}$ (s). The dissimilarities between the XANES features in the $\mathrm{Cu}$ sorbed samples and the tenorite and plancheite XANES features suggest that the sorbed $\mathrm{Cu}$ complexes are not forming phases with similar local atomic structure as these minerals.

\section{EXAFS results}

The $\mathrm{k}^{3}$-weighted EXAFS spectra for the $\mathrm{Cu}$-sorbed clay minerals and select standards are presented in Figure 3. In all of the clay mineral samples, the spectra are dominated by a single sinusoidal wave resulting from backscattering off of $\mathrm{O}$ atoms in the first atomic shell. In the samples incubated at high $I$ there is a small shoulder present at the beginning of the first oscillation peak. This feature is not present in the aqueous copper standard nor the clay samples equilibrated at low $I$, yet is present in the $\mathrm{Cu}(\mathrm{OH})_{2}$ mineral spectra.

To isolate atomic-shell contributions further, the $\chi$ spectra were Fourier transformed. The modulus of the FT are presented in Figure 4. The first peak in the FT spectra centered at $1.5 \AA$ is indicative of $\mathrm{O}$ backscattering atoms. In the clay-mineral samples equilibrated at high $I$ there exists a second peak in the FT spectra centered at $2.2 \AA$ that is due to backscattering

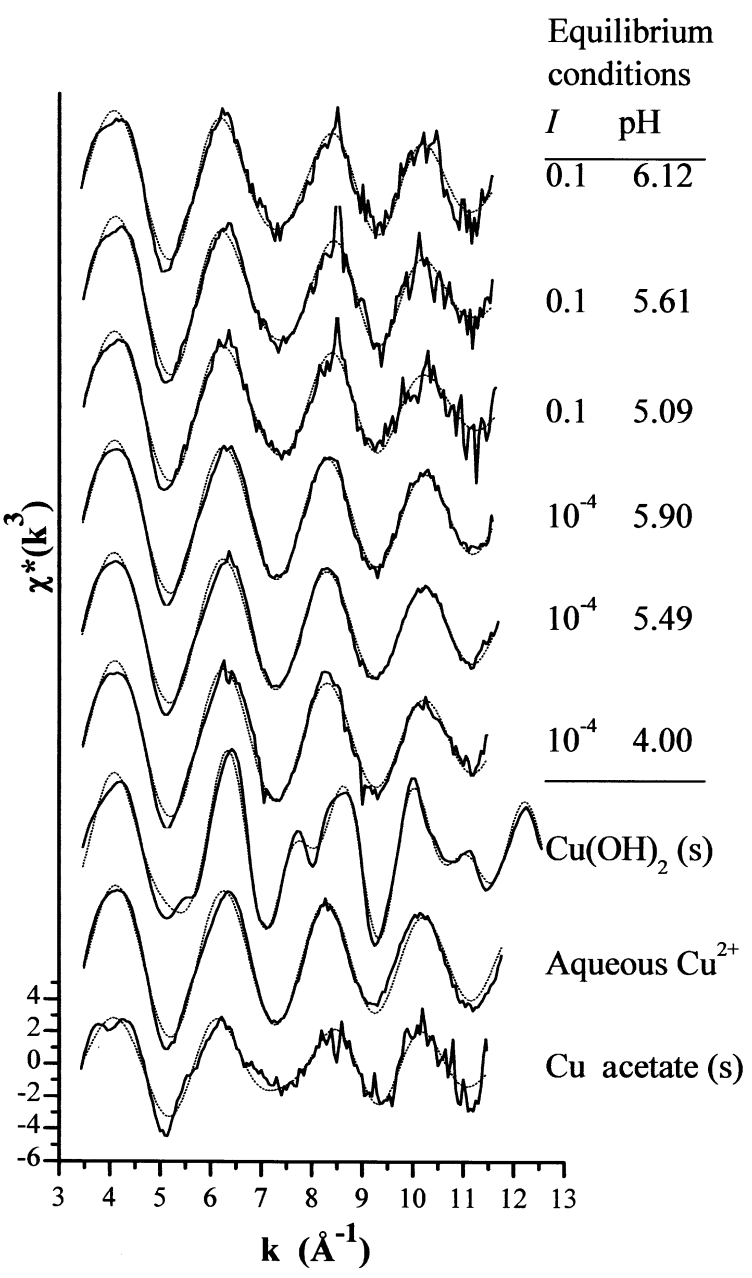

Figure $3 . \mathrm{k}^{3}$ weighted $\chi$ spectra of $\mathrm{Cu}$ sorbed on montmorillonite samples at different $\mathrm{pH}$ and ionic strengths. The amount of $\mathrm{Cu}$ sorbed on each sample is listed in Table 1. Three reference mineral spectra are also included for comparison of features. The dashed lines are best fits of data.

from a second-neighbor atomic shell. Figure 5 shows the intensity of this peak relative to the hydrated copper sorbed at low $I$. Peaks further out in the clay-mineral FT spectra are too small to identify with any confidence; however, they are probably due to multiple-scattering effects (Cheah et al., 1998, 2000; Farquhar et al., 1996), as well as backscattering structural atoms from the montmorillonite mineral. The position of the second peak matches that of the $\mathrm{Cu}-\mathrm{Cu}$ backscattering peak in $\mathrm{Cu}$ acetate, and has a decreased R-space position as compared to the $\mathrm{Cu}-\mathrm{Cu}$ backscatterer observed in the mineral $\mathrm{Cu}(\mathrm{OH})_{2}(\Delta \sim 0.32 \AA)$. Thus, the FT modulus in the high- $I$ samples suggests that the local atomic structure of the complexes formed on the clay minerals is different from that of $\mathrm{Cu}(\mathrm{OH})_{2}$ (s). Both montmorillonite and beidellite have similar features, suggesting that the complexation mechanism is the same in the two smectite minerals. At low $I$ there were no significant 


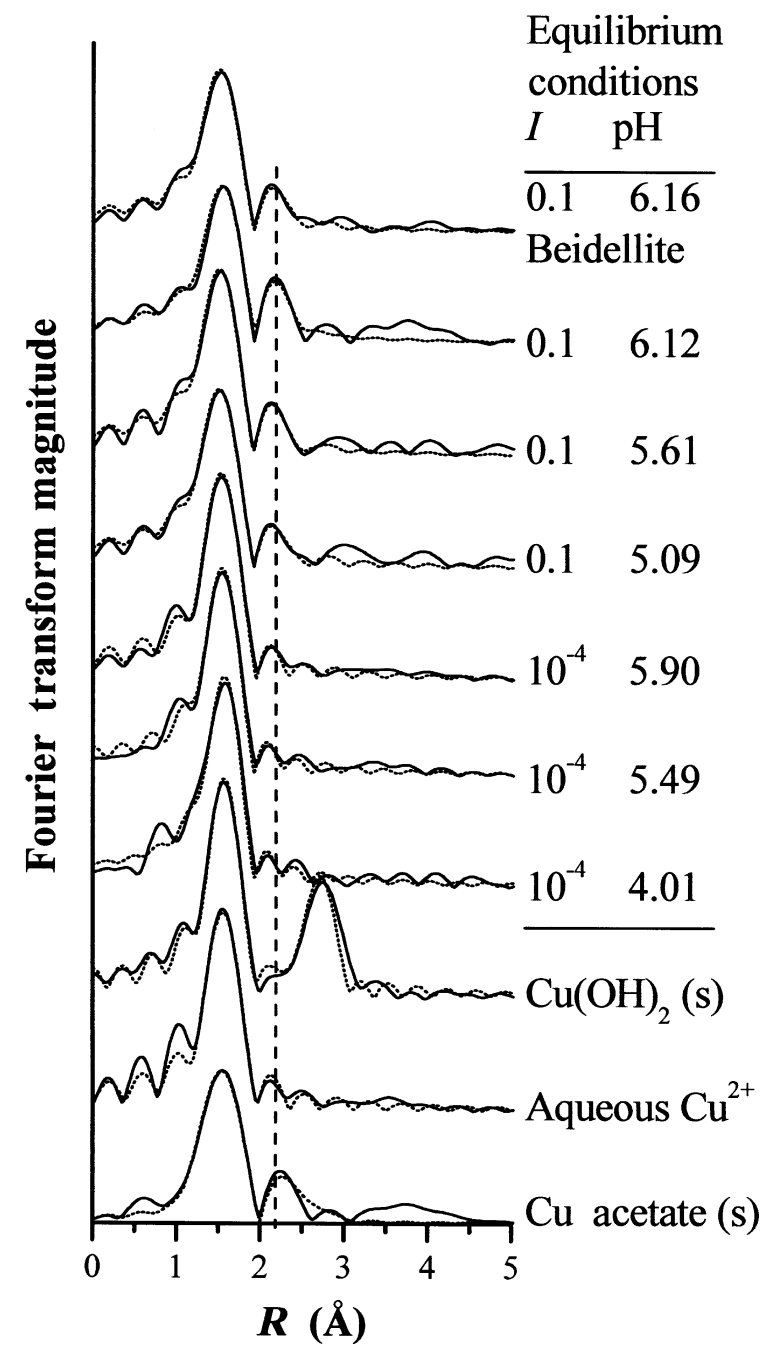

Figure 4. Fourier transform modulus and best fits for $\mathrm{Cu}$ sorbed on montmorillonite and beidellite samples at different $\mathrm{pH}$ and ionic strengths. The amount of $\mathrm{Cu}$ sorbed on each sample is listed in Table 1. Three reference mineral spectra are also included for comparison of features. The dashed lines are best fits of data. The parameters used in fitting are reported in Table 1.

second-shell peaks observed in the FT spectra, indicating that the local atomic environment surrounding the $\mathrm{Cu}$ consist of a single shell with a similar coordination environment as aqueous $\mathrm{Cu}$.

The fitting results are listed in Table 1. For the low- $I$ samples, only a single backscattering $\mathrm{O}$ shell consisting of $\sim 4 \mathrm{O}$ atoms at a bond distance of $1.94 \AA$ was fit. This local atomic shell is consistent with the coordination observed in the aqueous $\mathrm{Cu}$ standard, and has been observed by other researchers (Morton et al., 2001). The axial-O atoms could be fit only if two shells were used and the coordination number was fixed. However, the axial $O$ shell was not fit in this study as it does not provide any additional information. This is consistent with the fitting approach used to fit both model compounds and $\mathrm{Cu}$ sorbed on mineral surfaces (Cheah

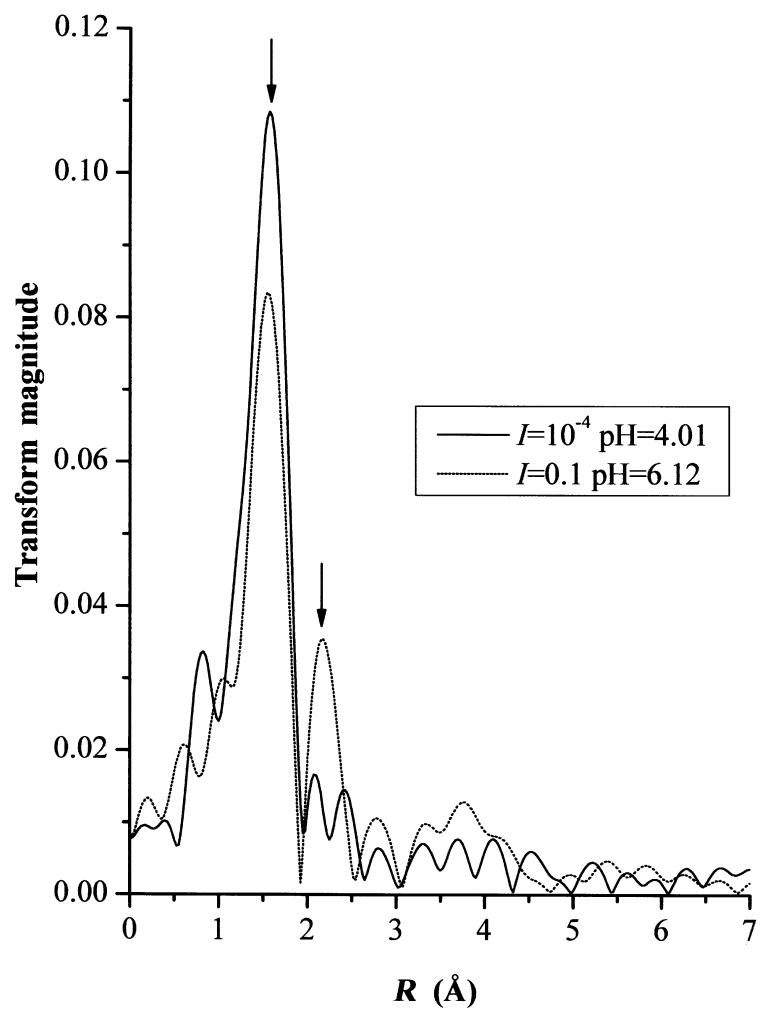

Figure 5. Fourier transform modulus for $\mathrm{Cu}$ sorbed on montmorillonite at $\mathrm{pH}=6.12$ and high ionic strength, and $\mathrm{pH}$ $=4.01$ and low ionic strength $\left(\Delta \mathrm{k}=3.4-11.8 \AA^{-1}\right)$. Samples are plotted on the same ordinate scale to illustrate the magnitude of second-shell backscattering contributions. The arrows indicate first- and second-shell backscattering features.

et al., 2000; Farquhar et al., 1996; Morton et al., 2001).

For the samples equilibrated at high $I$, two atomic shells were fit. One of the shells consisted of $\sim 4 \mathrm{O}$ atoms at $1.95 \AA$, and the other consisted of a $\mathrm{Cu}$ atom with an average bond distance of $2.64 \AA$. The O-bond distances are similar to those observed in hydrated $\mathrm{Cu}^{2+}$ and many covalently bonded $\mathrm{Cu}$ molecules (Cheah et al., 2000; Kau et al., 1987; Palladrino et al., 1993). However, the $\mathrm{Cu}-\mathrm{Cu}$ bond distances are significantly shorter than the $\mathrm{Cu}-\mathrm{Cu}$ bond distances observed in copper oxides and hydroxides $(2.95 \AA)$. The possibility that the second shell fit consisted of a structural atom such as $\mathrm{Si}$ or $\mathrm{Al}$ from the clay mineral was tested. Based on the poor fit in the RSF and investigation of the back transform (Figure 6), it was concluded that the second shell in the EXAFS spectra was a $\mathrm{Cu}$ atom. Figure 6 shows the back transformed second shell and the respective fit using $\mathrm{Cu}$ and $\mathrm{Al}$ second-shell backscatterers. The fit of the second shell with a $\mathrm{Cu}$ atom resulted in a lower residual (residual $=19$ ) than fitting the second shell with an $\mathrm{Al}$ atom (residual $=38$ ). In addition, fitting with the $\mathrm{Cu}$ second-shell backscatterer resulted in bond distance and coordination numbers that were consistent with the RSF and k-space fitting results, while results from fitting with an Al backscatterer were inconsistent. 


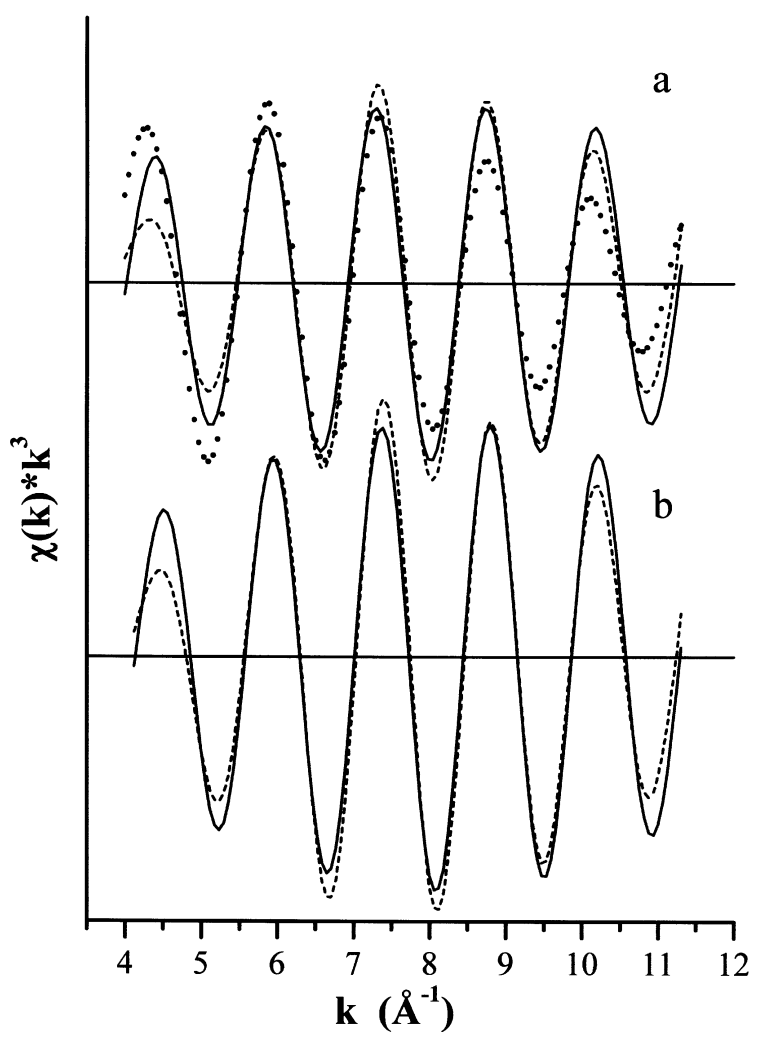

Figure 6. Backtransforms $(\Delta \mathrm{R}=1.9-2.5 \AA)$ of (a) second shell in Fourier transform modulus of montmorillonite sample incubated at $I=0.1 \mathrm{pH}=6.12$, and (b) $\mathrm{Cu}$ acetate sample. The dashed lines are best fits using a single $\mathrm{Cu}$ backscatterer atom and the dotted line in panel a is best fit using a single Al backscatterer atom.

Copper acetate, which has a $\mathrm{Cu}-\mathrm{Cu}$ backscatterer at $2.62 \AA$ was used to further investigate the spectral features and contributions in the EXAFS spectra from a short $\mathrm{Cu}-\mathrm{Cu}$ backscattering pair. Peak position in the RSF (Figure 4) and back-transform oscillations (Figure 6) for the $\mathrm{Cu}-\mathrm{Cu}$ backscatterer in $\mathrm{Cu}$ acetate and the high- $I$ sorption samples are identical, providing further evidence that the second-shell backscatterer in the samples equilibrated at high $I$ is $\mathrm{Cu}$ and not structural Al or Si from the clay mineral. The average coordination number for the second shell is 0.55 . This low coordination is indicative of small molecular units with minimal backscattering amplitude (Cheah et al., 1998; Farquhar et al., 1996), and is affected by the inherent error in coordination number derived from fitting second-shell backscatterers $( \pm 25 \%)$. Fitting the model compound $\mathrm{Cu}$ acetate, which is a dimer, also gave a coordination number $<1$ (0.84). Another explanation for the low coordination number may be that the EXAFS spectra represent an average of all $\mathrm{Cu}$ in the sample. Therefore, some of the $\mathrm{Cu}$ may exist as monomers and thus dilute the overall coordination number obtained from fitting. Thus, the EXAFS spectroscopy data reveal that at high $I$, $\mathrm{Cu}$ is sorbing as complexes coordinated by $\sim 4 \mathrm{O}$ atoms in the first atomic shell and $\sim 1 \mathrm{Cu}$ atom in the second atomic shell. This is in agreement with the XANES spectra.

Attempts to fit an $\mathrm{Al}$ or $\mathrm{Si}$ atom as a third atomic backscatterer from the montmorillonite samples equilibrated at high $I$ were successful, yielding $0.44 \mathrm{Al}$ or $\mathrm{Si}$ atoms at $3.03 \AA$ (fit not shown). However, the contribution of this backscatterer to the overall spectra was $<5 \%$, leading to poor confidence in the fit results. Such a small contribution to the overall spectra is not surprising since not all the $\mathrm{Cu}$ atoms are coordinated to the mineral in multi-nuclear sorption, and $\mathrm{Si}$ or $\mathrm{Al}$ atomic shells that are $>3 \AA$ away would be weak backscatterers, thus making XAFS contributions difficult to measure.

\section{EPR results}

Spectra from the EPR experiments are presented in Figure 7. An isotropic absorption line at $g=2.184$ is present in the spectrum for the aqueous copper nitrate sample. Because of the free tumbling of the hydrated $\mathrm{Cu}$ cation, the hyperfine coupling constants are averaged, resulting in a single isotropic resonance (Clementz et al., 1973; Hyun et al., 2000). Similarly, the spectrum for the montmorillonite sample equilibrated with $\mathrm{Cu}$ at low $I$ also shows an isotropic resonance at $\mathrm{g}=2.184$, suggesting that the adsorbed $\mathrm{Cu}$ has a coordination environment similar to that of aqueous $\mathrm{Cu}^{2+}$. The free tumbling of the adsorbed $\mathrm{Cu}$ indicates that the atom is unrestricted by the adsorption forces from the permanent charge on the montmorillonite, and that there are several layers of water in the interlayer. In contrast, spectra for the samples equilibrated at high $I$ yield only a small resonance feature at $\mathrm{g}=2.003$, which is the free-radical resonance commonly present in clay minerals (Clementz et al., 1973) and is shown in the hydrated montmorillonite blank in Figure 7. The loss of $\mathrm{Cu}$-derived resonance features in spectra for the high- $I$ equilibrated samples probably occurs because of dipolar and spin interactions between $\mathrm{Cu}$ atoms in multinuclear complexes (Hyun et al., 2000; McBride, 1982a; Weesner and Bleam, 1997; Xia et al., 1997b). The absence of these features does not indicate inner-sphere sorption, because $\mathrm{Cu}$ adsorbed as inner-sphere complexes on Al oxide has a distinct anisotropic rigid limit of $\mathrm{g}_{\perp} \sim 2.07$ and $\mathrm{g}_{\|}=$ 2.35 with $\mathrm{A}_{2}=155$ gauss (Martinez and McBride, 2000; McBride et al., 1984). The EPR spectra for the high- $I$ samples thus suggest that $\mathrm{Cu}$ is not sorbed by innersphere complexation, but instead exists as multinuclear complexes. This sorption mechanism is consistent with the EXAFS results.

\section{DISCUSSION}

\section{Sorption as a function of $\mathrm{pH}$}

Bradbury and Baeyens (1999) modeled proton sorption on clay-mineral edges using two types of surface hydroxyl groups, each capable of taking a positive, 


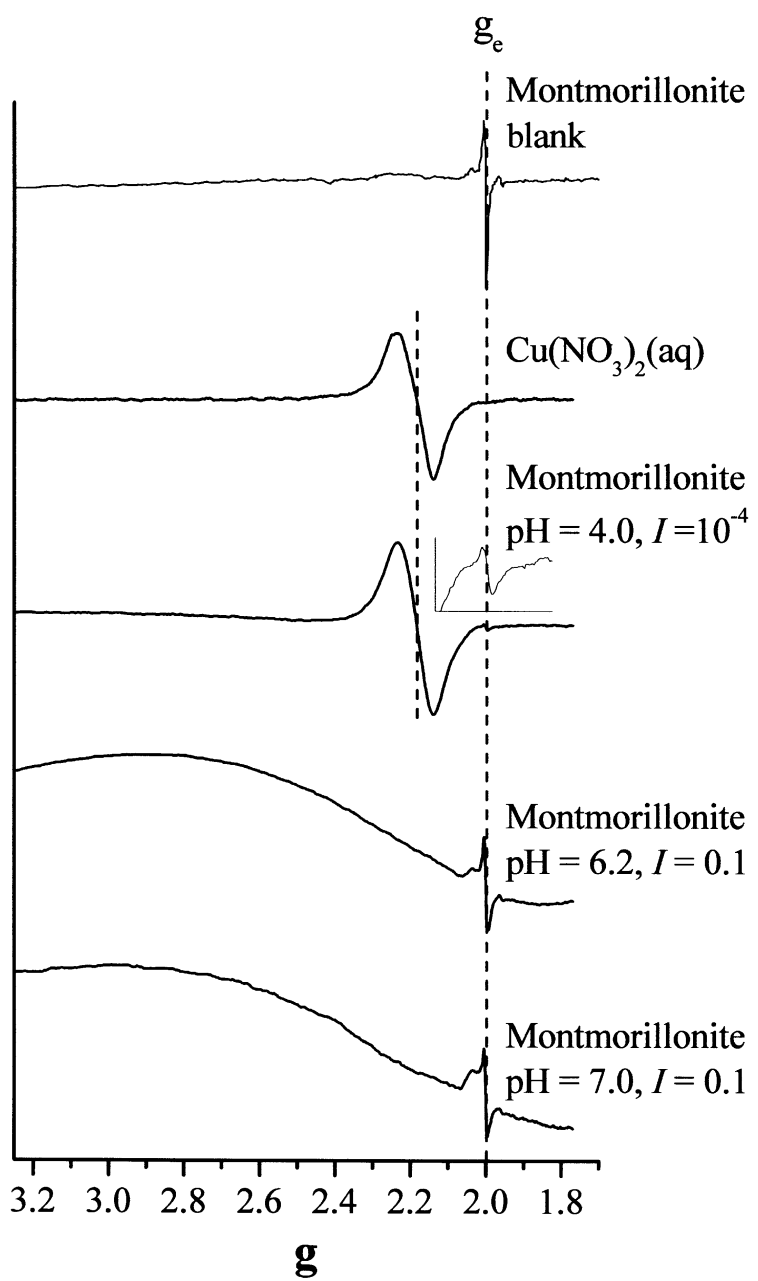

Figure 7. EPR spectra of $\mathrm{Cu}$ sorbed on montmorillonite as a function of $\mathrm{pH}$ and ionic strength. $\mathrm{g}_{\mathrm{e}}$ is the free electron resonance at 2.003. A montmorillonite blank sample (no $\mathrm{Cu}$ ) and aqueous $\mathrm{Cu}^{2+} \mathrm{EPR}$ spectra are shown for reference. Inset on montmorillonite is zoomed in to show features since ordinate scales are different for each spectra.

negative or zero charge. The first type of hydroxyl was said to have a strong affinity for metal cations and the second was described as a site with a much weaker affinity (Bradbury and Baeyens, 1999). Stadler and Schindler (1993) suggested that the silanol groups on the edge sites are acids that can dissociate protons becoming negatively charged, but can only form electrostatic bonds with cations, and that the aluminol groups can be either proton acceptors or donors capable of forming covalent bonds with metal cations. This description is analogous to the weak and strong affinity hydroxyl functional groups that Bradbury and Baeyens (1999) fit in their model. In the high- $I$ equilibrated system we observed a distinct increase in sorption as a function of $\mathrm{pH}$. This behavior is a classical $\mathrm{pH}$ edge that suggests sorption on hydroxyl functional groups. Subtracting the $20 \%$ of absorption which occurs as non-pH dependent sorption (Figure 1 shows that $20 \%$ of the $\mathrm{Cu}$ sorbed is
non-pH dependent), the midpoint of the $\mathrm{pH}$ edge occurs at $\mathrm{pH}=$ 5.7. Farrah and Pickering (1976) titrated $\mathrm{Cu}$ montmorillonite suspensions and found that the midpoint occurred at $\sim 6.1$. Stadler and Schindler (1993) observed a midpoint at $\mathrm{pH} 5.8$ using similar equilibrium conditions to those in our study (i.e. $\mathrm{Cu}$ on montmorillonite at $I=0.1 \mathrm{M}$, solid-solution $=0.01$, initial $[\mathrm{Cu}]=$ $\left.1 \times 10^{-4} \mathrm{M}\right)$. Stadler and Schindler (1993) did not have $20 \%$ permanent charge difference, but instead observed and modeled $\sim 10 \%$ permanent charge difference. The differences may be a result of clay treatment and the higher initial $\mathrm{Cu}$ concentration.

Based on the above discussion, one may interpret the behavior of $\mathrm{Cu}$ sorption observed in the $\mathrm{pH}$ edge to be a result of sorption of $\mathrm{Cu}$ on aluminol functional groups. Fitting a two-site sorption model, Stadler and Schindler (1993) proposed that the predominant $\mathrm{Cu}$ sorption mechanism under high- $I$ equilibration is a monodentate $\mathrm{CuOH}^{+}$complex with structural $\mathrm{AlO}^{-}$functional groups. Undabeytia et al. (2002) modeled $\mathrm{Cu}^{2+}$ sorption on montmorillonite using a two-site model that included planar and edge sorption. They found that the $\mathrm{Cu}$ sorption maximum for the edge sites was $\sim 22 \mathrm{mmol} \mathrm{kg}^{-1}$, which is similar to the aluminol edgesite capacity of $22.4 \mathrm{mmol} \mathrm{kg} \mathrm{m}^{-1}$ reported by Zachara and Mckinley (1993) who based their value on particle diameter, structural formula and crystallographic dimensions. Modeling sorption data clearly shows the importance of edge-site sorption, but these models usually neglect multinuclear complexation. Results from our molecular-level experiments show that multinuclear $\mathrm{Cu}$ complexation is the predominant sorption mode at high $I$.

\section{Surface complexation mechanism}

Copper has been reported to occur in four common dimer configurations (Cheah et al., 1998). Based on similarities in bond distances and XANES features, Cheah et al. (1998) proposed that $\mathrm{Cu}$-dimer complexes formed on the surface of silicon dioxide had a structural configuration similar to $\mathrm{Cu}$ acetate, composed of two square pyramids linked by a weak metal-metal bond along the axial direction. Multinuclear hydrolysis complexes with the formula $\mathrm{Cu}_{2}(\mathrm{OH})_{2}^{2+}(\mathrm{aq})$ are the most common aqueous hydrolysis products (Baes and Mesmer, 1986); however, calculations reveal that $\mathrm{Cu}_{2}(\mathrm{OH})_{2}^{2+}(\mathrm{aq})$ is $<1 \%$ of the total $\mathrm{Cu}$ in our initial solutions and $\mathrm{Cu}(\mathrm{OH})^{+}(\mathrm{aq})$ comprises $1.5 \%$. The $\mathrm{Cu}-\mathrm{Cu}$ distance in $\mathrm{Cu}_{2}(\mathrm{OH})_{2}^{2+}(\mathrm{aq})$ should be similar to the $\mathrm{Cu}(\mathrm{OH})_{2}$ (s) (Cheah et al., 1998) which is at least $0.3 \AA$ longer than the bond distances observed in this study. The minerals shattuckite and plancheite consist of $\mathrm{Cu}$ oxide trioctahedral layers sandwiched between two silicon tetrahedra chains arranged in a non-continuous sheet (Evans and Mrose, 1977). The chain silicate sheets are adjoined to adjacent $\mathrm{Si}$ tetrahedral sheets and chains by ribbons of four-fold coordinated $\mathrm{Cu}$ atoms that edge- 
share $\mathrm{O}$ ligands. These ribbons have similar structural configurations to the $\mathrm{Cu}-\mathrm{Cu}$ bonds in the $\mathrm{Cu}(\mathrm{OH})_{2}$ (s). However, unlike $\mathrm{Cu}(\mathrm{OH})_{2}$ (s), which has $\mathrm{Cu}-\mathrm{Cu}$ separations of $2.95 \AA$, the $\mathrm{Cu}$ ribbons in shattuckite and plancheite are $2.64 \AA$ apart (Farquhar et al., 1996). The shorter distance in the $\mathrm{Cu}$ ribbons is due to the structural confinements imposed by attachment to the tetrahedral$\mathrm{Si}$ chains. The $\mathrm{Cu}$ dimers on montmorillonite may be attached on several locations on the edge of the montmorillonite that creates a structural confinement analogous to the $\mathrm{Cu}$ ribbons in shattuckite or plancheite, thus allowing for similar short $\mathrm{Cu}-\mathrm{Cu}$ separations.

Further evidence for the formation of the $\mathrm{Cu}$ dimers instead of monomers is provided by comparing the second derivative XANES spectra of our samples with those of Cheah et al. (1998) (Figure 8). The results of Cheah et al. (1998) showed that $\mathrm{Cu}$ sorbed on amorphous $\mathrm{SiO}_{2}$ at loading levels of $6-10 \mathrm{mmol} \mathrm{kg}^{-1}$ existed as multinuclear-dimer complexes, while $\mathrm{Cu}$ sorbed on $\mathrm{Al}_{2} \mathrm{O}_{3}$ under the same equilibrium conditions existed as inner-sphere mononuclear complexes. The inner-sphere complexation mechanism was based on the fitting of the second peak in the Fourier transform with an $\mathrm{Al}$ atom located $2.83 \AA$ away from the $\mathrm{Cu}$ atom, as well as a distinct decrease in the position of the maximum amplitude peak in the back transformed second peak, which is consistent with lighter backscatterers (Cheah et al., 1998).

The work of Morton et al. (2001) showed that $\mathrm{Cu}$ forms a multinuclear precipitate on the surface of montmorillonite with a structural arrangement similar to the $\mathrm{Cu}(\mathrm{OH})_{2}$ mineral, i.e. $\mathrm{Cu}-\mathrm{Cu}$ separations of $\sim 2.98 \AA$. The $\mathrm{Cu}$ loading in the study of Morton et al. (2001) ranged from 40 to $97 \mathrm{mmol} \mathrm{kg}^{-1}$, which is several times the loading level in our samples incubated at high $I$. In addition, in the suspensions in which significant $\mathrm{Cu}$ backscatterers were observed at $2.98 \AA$, the initial $\mathrm{Cu}$ concentration was saturated with respect to $\mathrm{CuO}(\mathrm{s})$, yet undersaturated with respect to $\mathrm{Cu}(\mathrm{OH})_{2}$ (s). Cheah et al. (2000) performed experiments of $\mathrm{Cu}$ loading on amorphous $\mathrm{SiO}_{2}$ using loading levels ranging from 112 to $146 \mathrm{mmol} \mathrm{kg}^{-1}$ and showed that at these higher sorption levels (as compared with their previous study (Cheah et al., 1998)), the $\mathrm{Cu}$ sorption complexes were multinuclear complexes with similar local atomic structure as $\mathrm{Cu}(\mathrm{OH})_{2}$ (s). Xia et al. (1997b) also found that $\mathrm{Cu}$ sorbed to $\mathrm{SiO}_{2}$ (s) as multinuclear complexes similar to the $\mathrm{Cu}(\mathrm{OH})_{2}$ mineral. In the experiments of Cheah et al. (2000) and Xia et al. (1997b), the initial solutions were undersaturated with respect to $\mathrm{CuO}(\mathrm{s})$ or $\mathrm{Cu}(\mathrm{OH})_{2}$ (s). Thus, we speculate that the differences between our results and those of Morton et al. (2001) are due to loading level.

Farquhar et al. (1996) suggested that the $\mathrm{Cu}$ dimers were sorbing by an inner-sphere complexation mechanism on the basal planes of the muscovite. In our study, complexation on the basal plane seems unlikely since the basal-oxygen atoms are completely coordinated in an ideal montmorillonite structure. Adsorption on the basal plane of the montmorillonite occurs predominantly through coulombic forces, and because the concentration of $\mathrm{Ca}$ is $>10^{3}$ times the $\mathrm{Cu}$ concentration, mass action dictates that $\mathrm{Ca}$ would out-compete $\mathrm{Cu}$ for the basalplane adsorption sites. The higher hydration energy of $\mathrm{Ca}$ over $\mathrm{Cu}$ suggests that $\mathrm{Ca}$ is unlikely to form innersphere complexes with the ligands at the steps, kinks and edges of the montmorillonite, while $\mathrm{Cu}$ can adsorb to these sites by inner-sphere complexation. Thus, we hypothesize that $\mathrm{Cu}$ is sorbing as dimers on silanol or aluminol functional groups that have incomplete coordination. Farquhar et al. (1996) sorbed $\mathrm{Cu}$ complexes on muscovite and reported that $\mathrm{Si}$ atoms could be fit as a third shell at $\sim 3.25 \AA$. In our study the results indicate that bond distances between the $\mathrm{Cu}$ and the structural $\mathrm{Si}$ and Al atoms are probably near $3.05 \AA$, which is consistent with $\mathrm{Cu}$ forming a corner-sharing bond with the structural ligands (Cheah et al., 1998).

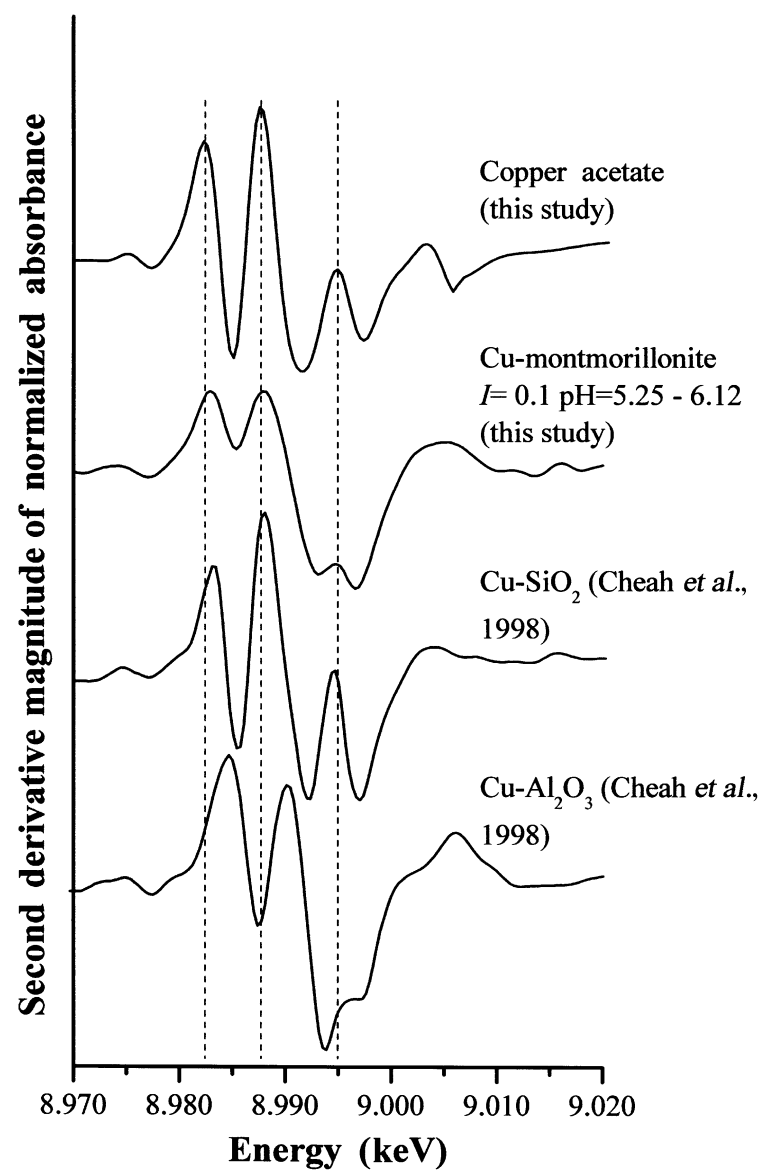

Figure 8. Comparison of second-derivative spectra from montmorillonite samples incubated at high $I$ averaged (see text) with results from $\mathrm{Cu}$ sorbed on amorphous $\mathrm{SiO}_{2}$ and $\mathrm{Al}_{2} \mathrm{O}_{3}$ as reported by Cheah et al. (1998). The $\mathrm{Cu}$ acetate spectrum was used to correlate the energy of the samples in the two studies. 
An example of $\mathrm{Cu}$ complexation mechanism on smectite minerals is illustrated in Figure 9. Formation of small metal multinuclear clusters have been proposed as precursors for the formation of more extensive precipitates (Cheah et al., 1998; Farquhar et al., 1996; Schlegel et al., 2001). CuO (s) has the lowest solubility followed by $\mathrm{Cu}(\mathrm{OH})_{2}$ (s) (Baes and Mesmer, 1986). Precipitation from solution usually starts with $\mathrm{Cu}(\mathrm{OH})_{2}$ (s) as a result of reaction kinetics (Cheah et al., 1998). The $\mathrm{Cu}(\mathrm{OH})_{2}$ (s) may then ripen to the more stable $\mathrm{CuO}$ phase if conditions are favorable. One can envision a similar process occurring for the $\mathrm{Cu}-\mathrm{Cu}$ dimers observed on the surface of the clay minerals used in this study. However, the results from two separate samples (data not shown) aged for 1 week showed no significant differences from the montmorillonite samples incubated for this study. If the $\mathrm{Cu}$ dimers were to convert to $\mathrm{Cu}(\mathrm{OH})_{2}$ (s) or $\mathrm{CuO}$ (s) complexes, it would require significant rearrangement of the structure (Cheah et al., 1998). Thus, we propose that the $\mathrm{Cu}-\mathrm{Cu}$ dimers sorbing onto the surface are stable complexes. $\mathrm{Cu}(\mathrm{OH})_{2}$ precipitates on the surface of montmorillonite as observed by Morton et al. (2001) appear to occur as a result of higher $\mathrm{Cu}$ loadings, possibly created from multi-layer sorption on the edge sites.

\section{CONCLUSIONS}

Macroscopic experiments were used to show that $\mathrm{Cu}$ had distinct uptake behavior as a function of ionic strength and interlayer cations on montmorillonite. We incubated our samples below the saturation indices for $\mathrm{CuO}(\mathrm{s})$ and $\mathrm{Cu}(\mathrm{OH})_{2}(\mathrm{~s})$, and used XAFS and EPR spectroscopies to show that $\mathrm{Cu}$ sorption on montmorillonite under high- $I$ conditions sorbs as $\mathrm{Cu}-\mathrm{Cu}$ dimers. These results are consistent with the results observed by Cheah (1998) and Farquhar (1996) for

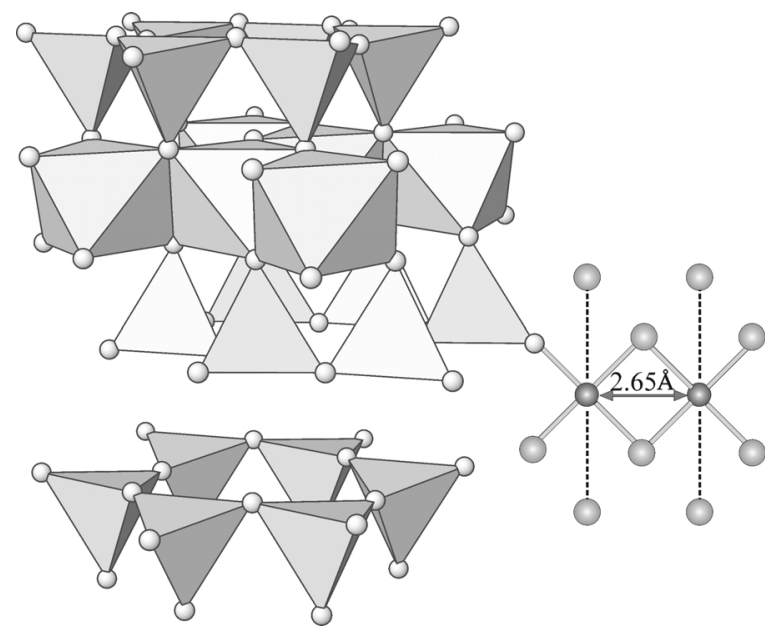

Figure 9. Illustration depicting possible $\mathrm{Cu}$ complexation mechanisms on smectite clays based on results from this study. sorption of $\mathrm{Cu}$ at low loading levels on $\mathrm{SiO}_{2}$ (s) and muscovite, respectively, and are in contrast to the $\mathrm{Cu}(\mathrm{OH})_{2}$-like complexes sorbed on montmorillonite (Morton et al., 2001) and $\mathrm{SiO}_{2}$ (s) (Cheah et al., 2000) when loading levels are high. It appears that $\mathrm{Cu}$ does not form surface precipitates having the 2:1 layer silicate structure as observed for $\mathrm{Ni}, \mathrm{Co}$ and $\mathrm{Zn}$ (Dahn et al., 2002; Schlegel et al., 1999, 2001). This is probably due to the Jahn-Teller distortion that creates an unfavorable energy when $\mathrm{Cu}$ is substituted in a symmetric octahedral environment (Burns, 1970).

Results from the beidellite sample indicate that the $\mathrm{Cu}$ sorption complex is the same as $\mathrm{Cu}$ sorption on montmorillonite. This suggests that the small degree of tetrahedral substitution in beidellite is not enough to induce formation of basal plane-sorbed $\mathrm{Cu}$ complexes similar to those observed by Farquhar et al. (1996) on muscovite.

\section{ACKNOWLEDGMENTS}

Support for this research was provided by a National Research Initiative-USDA grant. Portions of this research were carried out at the Stanford Synchrotron Radiation Laboratory (SSRL), a national user facility operated by Stanford University on behalf of the US Department of Energy, Office of Basic Energy Sciences. The SSRL Structural Molecular Biology Program is supported by the Department of Energy, Office of Biological and Environmental Research, and by the National Institutes of Health, National Center for Research Resources, Biomedical Technology Program. A portion of the research described in this paper was performed in the Environmental Molecular Sciences Laboratory, a national scientific user facility sponsored by the Department of Energy's Office of Biological and Environmental Research and located at the Pacific Northwest National Laboratory (PNNL). The PNNL is operated for DOE by Battelle Memorial Institute under contract DE-AC06-76RL0 1830. D. Strawn is grateful to Glenn Waychunas, Mickey Gunter and the staff at SSRL for discussions on experimental details. Reviewers' comments and edits are also greatly appreciated.

\section{REFERENCES}

Ankudinov, A.L., Ravel, B., Rehr, J.J. and Conradson, S.D. (1998) Real space multiple scattering calculation of XANES. Physical Review B, 58, 7565.

Baes, C.F. and Mesmer, R.E. (1986) The Hydrolysis of Cations. Krieger Publishing Co., Malabar, Florida.

Bradbury, M.H. and Baeyens, B. (1999) Modelling the sorption of $\mathrm{Zn}$ and $\mathrm{Ni}$ on Ca-montmorillonite. Geochimica et Cosmochimica Acta, 63, 325-326.

Burns, R.G. (1970) Mineralogical Applications of Crystal Field Theory. Cambridge University Press, Cambridge, UK.

Cheah, S.-F., Brown, G.E., Jr. and Parks, G.A. (1998) XAFS spectroscopy study of $\mathrm{Cu}(\mathrm{II})$ sorption on amorphous $\mathrm{SiO}_{2}$ and $\gamma-\mathrm{Al}_{2} \mathrm{O}_{3}$ : Effect of substrate and time on sorption complexes. Journal of Colloid and Interface Science, 208, $110-128$.

Cheah, S.-F., Brown, G.E., Jr. and Parks, G.A. (2000) XAFS study of $\mathrm{Cu}$ model compounds and $\mathrm{Cu}^{2+}$ sorption on amorphous $\mathrm{SiO}_{2}, \gamma-\mathrm{Al}_{2} \mathrm{O}_{3}$, and anatase. American Mineralogist, 85, 118-132. 
Clementz, D.M., Pinnavaia, T.J. and Mortland, M.M. (1973) Stereochemistry of hydrated copper(II) ions on the interlamellar surfaces of layer silicates. An electron spin resonance study. The Journal of Physical Chemistry, 77, 196-200.

Dahn, R., Scheidegger, A.M., Manceau, A., Schlegel, M., Baeyens, B., Bradbury, M.H. and Morales, M. (2002) Neoformation of $\mathrm{Ni}$ phyllosilicate upon $\mathrm{Ni}$ uptake on montmorillonite: A kinetic study by powder and polarized extended X-ray absorption fine strucuture spectroscopy. Geochimica et Cosmochimica Acta, 66, 2335-2347.

Dahn, R., Scheidegger, A.M., Manceau, A., Schlegel, M.L., Baeyens, B., Bradbury, M.H. and Chateigner, D. (2003) Structural evidence for the sorption of $\mathrm{Ni}(\mathrm{II})$ atoms on the edges of montmorillonite clay minerals: A polarized X-ray absorption fine structure study. Geochimica et Cosmochimica Acta, 67, 1-15.

Di Leo, P. and O'Brien, P. (1999) Nuclear magnetic resonance (NMR) study of $\mathrm{Cd}^{2+}$ sorption on montmorillonite. Clays and Clay Minerals, 47, 761-768.

Evans, H.T. and Mrose, M.E. (1977) The crystal chemistry of the hydrous copper silicates, shattuckite and plancheite. American Mineralogist, 62, 491-502.

Farquhar, M.L., Charnock, J.M., England, K.E.R. and Vaughan, D.J. (1996) Adsorption of Cu(II) on the (0001) plane of mica: A REFLEXAFS and XPS study. Journal of Colloid and Interface Science, 177, 561-567.

Farrah, H. and Pickering, W.F. (1976) The sorption of copper species. Australian Journal of Chemistry, 1976(29), 1167-1176.

Ford, R.G. and Sparks, D.L. (1998) The potential formation of secondary hydrotalcite-like precipitates during $\mathrm{Zn}$ and $\mathrm{Cu}$ sorption to pyrophyllite. Mineralogical Magazine, 62A, $462-463$.

Helmy, A.K., Ferreiro, E.A. and deBussetti, S.G. (1994) Cation exchange capacity and condition of zero charge of hydroxylAl montmorillonite. Clays and Clay Minerals, 42, 444-450.

Hyun, S.P., Cho, Y.H., Kim, S.J. and Hahn, P.S. (2000) Cu(II) sorption mechanisms on montmorillonite: An electron paramagnetic resonance study. Journal of Colloid and Interface Science, 222, 254-261.

Kau, L.S., Spira-Solomon, D.J., Penner-Hahn, J.E., Hodgson, K.O. and Solomon, E.I. (1987) X-ray absorption edge determination of the oxidation state and coordination number of copper: Application to the Type 3 site in Rhus vernicifera Laccase and its reaction with oxygen. Journal of the American Chemical Society, 109, 6433-6442.

Lytle, F.W., Greegor, R.B., Sandstrom, D.R., Marques, E.C., Wong, J., Spiro, C.L., Huffman, G.P. and Huggins, F.E. (1984) Nuclear Instrumental Methods, 226, 542-548.

Marshal, C.E. (1935) Layer lattices and the base exchange clays. Zeitschrift für Kristallographie und Mineralogie, 91, $443-449$.

Martinez, C.E. and McBride, M.B. (2000) Aging of coprecipitated $\mathrm{Cu}$ in alumina: Changes in structural location, chemical form, and solubility. Geochimica et Cosmochimica Acta, 64, 1729-1736.

McBride, M.B. (1982a) $\mathrm{Cu}^{2+}$ sorption characteristics of aluminum hydroxide and oxyhydroxides. Clays and Clay Minerals, 30, 21-28.

McBride, M.B. (1982b) Hydrolysis and dehydration reactions of exchangeable $\mathrm{Cu}^{2+}$ on hectorite. Clays and Clay Minerals, 30, 200-206.

McBride, M.B. and Bouldin, D.R. (1984) Long-term reactions of copper(II) in a contaminated calcareous soil. Soil Science Society of America Journal, 48, 56-59.

McBride, M.B., Fraser, A.R. and McHardy, W.J. (1984) $\mathrm{Cu}^{2+}$ interaction with microcyrstalline gibbsite. Evidence for oriented chemisorbed copper ions. Clays and Clay
Minerals, 32, $12-18$

Morton, J.D., Semrau, J.D. and Hayes, K.F. (2001) An X-ray absorption spectroscopy study of the structure and reversibility of copper adsorbed on montmorillonite clay. Geochimica et Cosmochimica Acta, 65, 2709-2722.

O’Day, P., Brown, G.E., Jr. and Parks, G.A. (1994) X-ray absorption spectroscopy of cobalt (II) multinuclear surface complexes and surface precipitates on kaolinite. Journal of Colloid and Interface Science, 165, 269-289.

Ozutsumi, K., Miyata, Y. and Kawashima, T. (1991) EXAFS and spectrophotometric studies on the structure of Mono and Bis(Aminocarboxylato) copper(II) complexes in aqueous solution. Journal of Inorganic Biochemistry, 1991(44), 97-108.

Palladrino, L., Della Long, S., Reale, A., Belli, M., Scafati, A., Onori, G. and Santucci, A. (1993) X-ray absorption near edge structure (XANES) of $\mathrm{Cu}(\mathrm{II})-\mathrm{ATP}$ and related compounds in solution: Quantitative determination of the distortion of the $\mathrm{Cu}$ site. Journal of Physical Chemistry, 98, 2720-2726.

Papelis, C. and Hayes, K.F. (1996) Distinguishing between interlayer and external sorption sites of clay minerals using $\mathrm{X}$-ray absorption spectroscopy. Colloids and Surfaces, 107, 89.

Ravel, B. (2001) ATOMS: crystallography for the X-ray absorption spectroscopist. Journal of Synchrotron Radiation, 8, 314-316.

Ressler, T. (1998) WinXAS: A program for X-ray absorption spectroscopy data analysis under MS-Windows. Journal of Synchrotron Radiation, 5, 118-122.

Savitzky, A. and Golay, M.J.E. (1964) Smoothing and differentiation of data by simplified least squares procedures. Analytical Chemistry, 36, 1627-1639.

Schecher, W. (1998) Mineql+ version 4.5. Environmental Research Software, Hallowell, Maine, USA.

Schindler, P.W., Liechti, P. and Westall, J.C. (1987) Adsorption of copper, cadmium and lead from aqueous solution to the kaolinite/water interface. Netherlands Journal of Agricultural Science, 35, 219-230.

Schlegel, M.L., Manceau, A., Chateigner, D. and Charlet, L. (1999) Sorption of metal ions on clay minerals I. Polarized EXAFS evidence for the adsorption of Co on the edges of hectorite particles. Journal of Colloid and Interface Science, 215, $140-158$.

Schlegel, M., Manceau, A., Charlet, L., Chatigner, D. and Hazemann, J. (2001) Sorption of metal ions on clay minerals. III. Nucleation and epitaxial growth of $\mathrm{Zn}$ phyllosilicate on the edge of hectorite. Geochimica et Cosmochimica Acta, 65, 4155-4170.

Sposito, G. (1989) The Chemistry of Soils. Oxford University Press, Inc., New York.

Stadler, M. and Schindler, P.W. (1993) Modeling of $\mathrm{H}^{+}$and $\mathrm{Cu}^{2+}$ adsorption on calcium-montmorillonite. Clays and Clay Minerals, 41, 288-296.

Stern, E.A. (1988) Theory of EXAFS. Pp. 3-51 in: X-ray Absorption: Principles, Applications, and Techniques of EXAFS, SEXAFS, and XANES (D.C. Koningsberger and R. Prins, editors) Wiley, New York.

Strawn, D.G. and Sparks, D.L. (1999) The use of XAFS to distinguish between inner- and outer-sphere lead adsorption complexes on montmorillonite. Journal of Colloid and Interface Science, 216, 257-269.

Towle, S.N., Bargar, J.R., Brown, G.E., Jr. and Parks, G.A. (1997) Surface precipitation of $\mathrm{Co}(\mathrm{II})(\mathrm{aq})$ on $\mathrm{Al}_{2} \mathrm{O}_{3}$. Journal of Colloid and Interface Science, 187, 62-82.

Undabeytia, T., Nir, S., Rytwo, G., Sereban, C., Morillo, E. and Maqueda, C. (2002) Modeling adsorption-desorption processes of $\mathrm{Cu}$ on edge and planar sites of montmorillonite. Environmental Science and Technology, 36, 2677-2683. 
Weesner, F.J. and Bleam, W.F. (1997) X-ray absorption and EPR spectroscopic characterization of the adsorbed copper(II) complexes at the boehmite (AlOOH) surface. Journal of Colloid and Interface Science, 196, 79-86.

Xia, K., Bleam, W. and Helmke, P.A. (1997a) Studies of the nature of $\mathrm{Cu}^{2+}$ and $\mathrm{Pb}^{2+}$ binding sites in soil humic substances using X-ray absorption spectroscopy. Geochimica et Cosmochimica Acta, 61, 2211-2221.

Xia, K., Mehadi, A., Taylor, R.W. and Bleam, W.F. (1997b) $\mathrm{X}$-ray absorption and electron paramagnetic resonance studies of $\mathrm{Cu}$ (II) sorbed to silica: Surface-induced precipitation at low surface coverages. Journal of Colloid and
Interface Science, 185, 252-257.

Zachara, J.M. and McKinley, J.P. (1993) Influences of hydrolysis on the sorption of metal cations by smectites: Importance of edge coordination reactions. Aquatic Sciences, 55, 1015-1621.

Zachara, J.M., Smith, S.C., McKinley, J.P. and Resch, C.T. (1993) Cadmium sorption on specimen and soil smectites in sodium and calcium electrolytes. Soil Science Society of America, 57, 1491-1501

(Received 11 August 2003; revised 8 December 2003; Ms. 827) 